\title{
Cone and seed characteristics of Juniperus excelsa (M. bieb) in Balochistan province, Pakistan
}

\author{
Muhammad Waseem Khan ${ }^{1}$, Afrasiab Khan Tareen ${ }^{1,2}$, Momina Tareen ${ }^{3}$ \\ and Imrana Niaz Sultan ${ }^{*}$
}

1. Department of Biotechnology, Faculty of Life Sciences and Informatics, Balochistan University of Information Technology Engineering and Management Sciences, Quetta, Pakistan

2. Department of Biotechnology, Kasetsart University, Chatuchak, Bangkok, 10900, Thailand

3. Department of Biochemistry, Faculty of Basic Science, Sardar Bahadur Khan Women's University, Quetta, Pakistan

*Corresponding author's email: imrana.niaz@buitms.edu.pk

Citation

Muhammad Waseem Khan, Afrasiab Khan Tareen, Momina Tareen and Imrana Niaz Sultan. Cone and seed characteristics of Juniperus excelsa (bieb) in Balochistan province, Pakistan. Pure and Applied Biology. Vol. 11, Issue 3, pp814-822. http://dx.doi.org/10.19045/bspab.2022.110082

\begin{tabular}{llll}
\hline \hline Received: 01/09/2021 & Revised: 13/11/2021 & Accepted: 19/11/2021 & Online First: 07/12/2021 \\
\hline \hline
\end{tabular}

\section{Abstract}

Juniperus excelsa is a coniferous plant of the Cupressaceae family widely preset in district Ziarat. The current study was aimed to study the physical characteristics of cones from Juniperus excelsa. The cones of Juniperus excelsa from about 120 randomly selected trees were collected from Kharwari Baba and Pechi (distt Ziarat), which were facing different aspects (east, west, north, and south). Various parameters, including cone weight, number of seeds per cone, cone diameter, seed weight and cutting test of seeds, were studied. There was no considerable difference in cone weight, cone diameter, number of seeds per cone, seed weight within one area. However, the average cone diameter and weight of Kharwari Baba was higher when compared to average cone diameter and weight of Pechi. The average number of seeds per cone and seed weight of Kharwari Baba was more when compared to average number of seeds per cone and seed weight of Pechi. There was a positive correlation between cone weight and diameter, cone diameter and number of seeds per cone. The current study serves as a primary study and the data will be helpful in future research on Juniperus excelsa in the region.

Keywords: Cone; Coniferous plant; Juniper; Juniperus excels

\section{Introduction}

Juniper (Juniperus excelsa. Bieb), also known as Greek juniper is a medium sized tree generally known as 'Sanober' in Urdu and 'Obushte' in Pashto. It is only found in some of the inner valleys of Himalaya and Balochistan at the altitude of $2000-4000 \mathrm{~m}$ above sea level. In Balochistan, juniper trees can be found in three regions, namely Ziarat, Zarghoon and Harboi in Kalat [1].

Junipers (Juniperus excelsa) are coniferous plants of the Cupressaceae family. There are about 50-67 species of Juniperus excelsa (taxonomically), distributed (widely) all over the northern hemisphere, from the south to tropical Africa and the Arctic, and central America [1]. 
Junipers tree vary in shape and size from tall trees (20-40 meter), to columnar or low spreading shrubs with long trailing branches $[1,2]$. They can be either monoecious or dioecious. The trees of Juniperus excelsa ( $\mathrm{J}$. excelsa) species are evergreen with needlelike and/or scale-like leaves. The female seed cones uniquely distinguish with fruit like (fleshy) coalescing scales forming a "cone"-like structure while fusing. The cones are about 4-27 milimeter (mm) long, and each cone has 1-12 hard-shelled, unwinged seeds. In certain species of $J$. excelsa trees, these "cones" are orange or brown-red in color, but in most, they are blue colored. The maturation time of juniper seeds varies between various species and ranges from 6-18 months post pollination. The male cones of $J$. excelsa species are similar to those of other Cupressaceae family, having about 6-20 scales; some species pollinate in the autumn however, maximum trees of $J$. excelsa outhouse their pollen in early spring $[2,3]$.

Many juniper species (J. chinensis, $J$. virginiana) have two types of leaves: needle like leaves and seedlings. Needle-like leaves are about 5-25 mm long and found only in older trees twigs. The leaves on mature plants of junipers are (typically) tiny scale like and overlapping. In certain species $(J$. communis, J. squamata), all the foliage is juvenile needle-like; these leaves possess no scales. In some species i.e., J. communis, the needles are interconnected at the base, while in some ( $J$. squamata), the needles appear with the stem of the tree, not jointed. The needle-leaves of juniper trees are sharp and hard, making the juvenile foliage very prickly and irritable in handling. This can be a valuable identification feature of the seedlings $[2,3]$.

The present study was aimed to study cones of $J$. excelsa; studying diameter, the weight of cones, number of seeds per cone, seed weight of $J$. excelsa and cutting test of seeds of $J$. excelsa.

\section{Materials and Methods}

About the area

Ziarat is a district in province Balochistan, Pakistan. The district is about $8850 \mathrm{ft}$. above the sea level. The juniper forest in Ziarat is the world's second largest. There are trees in the valley which are more than 7000 years old.

The area is cool in May-August (summer). The weather gets cold in autumn and extremely cold from November to March. In winter, the area gets a good amount of snowfall. The average rainfall is about 20.60 $\mathrm{mm}(1.3 \mathrm{~mm} 53.8 \mathrm{~mm})$. Most rainfall is received from January to March and between July to August. In the winter, the temperature often falls below freezing point, ranging from -16 to $20^{\circ} \mathrm{C}$.

\section{Sample collection}

The cones of $J$. excelsa were collected from two areas of district Ziarat (Pechi and Kharwari Baba). Pechi is situated about 8 $\mathrm{km}$ before Ziarat city and Kharwari Baba is situated about 9-10 km away from Ziarat situated in the western area of Ziarat city. The cones were collected from two different mountains of one area facing different aspects (east, west, north, and south). The sampling sites are hereafter termed as Site 1: Kharwari Baba facing north; Site 2: Kharwari Baba facing east; Site 3: Pechi facing north; Site 4: Pechi facing west south. The juniper cones were collected from 25 to 30 randomly selected trees of (about 300 to 350 cones) juniper in each mountain. The total numbers of 100 cones were processed from each mountain, 200 cones from one area and 400 cones as a whole from two areas.

\section{Sample analysis}

The collected cones were weighed and their diameter was analyzed. For the weighing of cones, an analytical balance was used and vernier caliper was used for the diameter of 
cones. Afterwards, the number of seeds present in each cone was analyzed by cutting them. The number of seeds present in each cone were counted and weighted with the help of analytical balance. Mean and standard error of cones weight, cones diameter and number of seeds in each cone was taken. Cones weight, cones diameter, and number of seeds in each cone were positively correlated with one and other. Cutting test of seeds was also performed; embryo was isolated from each and every seed and were examined under the microscope.

For statistical analyses, IBM SPSS Statistics Version 22 was used.

\section{Results}

\section{Cone diameter}

The diameters of cones of $J$. excelsa were measured. The diameter of cones collected from site 1 ranged from $8.1 \mathrm{~mm}$ to $12.2 \mathrm{~mm}$. Most of the cones were found in the range of $10 \mathrm{~mm}-10.9 \mathrm{~mm}(\mathrm{n}=43)$, followed by $11 \mathrm{~mm}-$ $11.9 \mathrm{~mm}(\mathrm{n}=38)$. The average cone diameter for this site (Site 1) was 10.621 \pm 0.082 (Table 1). Whereas the cones collected from site 2 ranged from $8.1 \mathrm{~mm}$ to $12.2 \mathrm{~mm}$. Most of the cones were found in the class $10 \mathrm{~mm}-$ $10.9 \mathrm{~mm}(\mathrm{n}=61)$ followed by $11 \mathrm{~mm}-11.9 \mathrm{~mm}$ $(n=24)$. The average cone diameter for this site (Site 2) was 10.482 \pm 0.071 (Table 1).

The diameter of cones collected from site 3 ranged from $6.8 \mathrm{~mm}$ to $12.7 \mathrm{~mm}$. Most of the cones were found in the range of $9 \mathrm{~mm}-$ $9.9 \mathrm{~mm} \quad(\mathrm{n}=32)$ followed by $8 \mathrm{~mm}-8.9 \mathrm{~mm}$ $(n=25)$. The average cone diameter for this site (Site 3) was 9.489 \pm 0.130 (Table 1). Whereas the cones collected from site 4 ranged from $6.2 \mathrm{~mm}$ to $12.1 \mathrm{~mm}$. Most of the cones were found in the class $9 \mathrm{~mm}-9.9 \mathrm{~mm}$ $(n=34)$ followed by $10 \mathrm{~mm}-10.9 \mathrm{~mm}$. The average cone diameter for this site was (Site 4) $9.382 \pm 0.122$ (Table 1).

The average cone diameter of site 1 and site 2 was slightly more when compared with the cones collected from site 3 and site 4 (Table. 1)

\section{Cone weight}

The weight of cones collected from site 1 ranged from $0.236 \mathrm{~g}$ to $0.893 \mathrm{~g}$. Most of the cones were found in the class $0.500 \mathrm{~g}-0.599 \mathrm{~g}$ $(n=36)$ followed by $0.400 \mathrm{~g}-0.499 \mathrm{~g}(\mathrm{n}=27)$. The average cone weight for this site (Site 1) was $0.542 \pm 0.012$ (Table 1). Whereas the cones collected from site 2 ranged from $0.298 \mathrm{~g}$ to $0.850 \mathrm{~g}$. Most of the cones were found in the class $0.400 \mathrm{~g}-0.499 \mathrm{~g} \quad(\mathrm{n}=45)$ followed by $0.500 \mathrm{~g}-0.599 \mathrm{~g} \quad(\mathrm{n}=27)$. The average cone weight for this site (Site 2) was $0.517 \pm 0.010$ (Table 1).

The weight of cones collected from site 3 ranged from $0.152 \mathrm{~g}$ to $0.629 \mathrm{~g}$. Most of the cones were found in the class $0.200 \mathrm{~g}-0.299$ $(n=34)$ followed by $0.300 \mathrm{~g}-0.399 \mathrm{~g}(\mathrm{n}=32)$. The average cone weight for this site (Site 3) was $0.336 \pm 0.010$ (Table 1). Whereas the cones collected from site 4 ranged from $0.185 \mathrm{~g}$ to $0.705 \mathrm{~g}$. Most of the cones were found in the class $0.300 \mathrm{~g}-0.399 \mathrm{~g} \quad(\mathrm{n}=39)$ followed by $0.200 \mathrm{~g}-0.299 \mathrm{~g} \quad(\mathrm{n}=32)$. The average cone weight for this site (Site 4) was $0.349 \pm 0.010$ (Table 1).

The average cone weight of site 1 and site 2 was slightly more when compared with the cones collected from site 3 and site 4 (Table 1).

\section{Number of seeds per cone}

The number of seeds per cone collected from site 1 ranged from 2 to 7 . Most of the seeds per cone were found in the range of 4 and 5 seeds $(n=30)$ followed by 3 seeds $(n=17)$ (Table 2). The average number of seeds per cone for this site (Site 1) was $4.320 \pm 0.116$ (Table 1). Whereas the number of seeds per cone collected from site 2 ranged from 1 to 6 . Most of the cones were found in the range of 4 seeds $(n=34)$ followed by 5 seeds $(n=24)$ (Table 2). The average number of seeds per cone for this site (Site 2) was 4.064 \pm 0.113 (Table 1). 
The number of seeds per cone collected from site 3 ranged from 1 to 7 . Most of the seeds per cone were found in the range of 2 and 3 seeds $(n=28)$ followed by 4 seeds $(n=21)$ (Table 2). The average number of seeds per cone for this site (Site 3) was $3.174 \pm 0.131$ (Table 1). Whereas the number of seeds per cone collected from site 4 ranged from 1 to 6 . Most of the cones were found in the range of 2 seeds $(n=33)$ followed by 3 seeds $(n=21)$ (Table 2). The average number of seeds per cone for this site (Site 4) was 3.2 \pm 0.132 (Table 1).

The average number of seeds per cone of site 1 and site 2 was slightly more when compared with the cones collected from site 3 and site 4 (Table 1).

\section{Seed weight}

The weight of seeds collected from site 1 ranged from $0.012 \mathrm{~g}$ to $0.068 \mathrm{~g}$. Most of the seeds were found in the class $0.020 \mathrm{~g}-0.029 \mathrm{~g}$ $(\mathrm{n}=32)$ followed by $0.030 \mathrm{~g}-0.039 \mathrm{~g}(\mathrm{n}=26)$. The average seed weight for this site (Site 1) was $0.034 \pm 0.001$ (Table 1). Whereas the seeds collected from site 2 ranged from $0.008 \mathrm{~g}$ to $0.0702 \mathrm{~g}$. Most of the seeds were found in the range of $0.030 \mathrm{~g}-0.039 \mathrm{~g}(\mathrm{n}=38)$ followed by $0.020 \mathrm{~g}-0.029 \mathrm{~g} \quad(\mathrm{n}=31)$. The average seed weight for this site (Site 2) was $0.032 \pm 0.0010$ (Table 1).

The weight of seeds collected from site 3 ranged from $0.004 \mathrm{~g}$ to $0.052 \mathrm{~g}$. Most of seeds were found in the range of $0.020 \mathrm{~g}-0.029 \mathrm{~g}$ $(n=35)$ followed by $0.010 \mathrm{~g}-0.019 \mathrm{~g}(\mathrm{n}=33)$. The average seed weight for this site (Site 3 ) was $0.023 \pm 0.0010$ (Table 1). Whereas the seeds collected from site 4 ranged from $0.011 \mathrm{~g}$ to $0.049 \mathrm{~g}$. Most of seeds were found in the range of $0.020 \mathrm{~g}-0.029 \mathrm{~g} \quad(\mathrm{n}=48)$ followed by $0.030 \mathrm{~g}-0.039 \mathrm{~g} \quad(\mathrm{n}=24)$. The average seed weight for this site (Site 4) was $0.026 \pm 0.0008$ (Table 1).

The average seed weight of site 1 and site 2 was slightly more when compared with the seeds collected from site 3 and site 4 (Table $1)$.

Table 1. Cone and seed characteristics of Juniperus excelsa studied at various sites in district Ziarat

\begin{tabular}{|c|c|c|c|c|}
\hline Area & $\begin{array}{c}\text { Average cone } \\
\text { diameter }\end{array}$ & $\begin{array}{c}\text { Average cone } \\
\text { weight }\end{array}$ & $\begin{array}{c}\text { Average number } \\
\text { of seeds per cone }\end{array}$ & $\begin{array}{c}\text { Average seed } \\
\text { weight }\end{array}$ \\
\hline Site 1, Mean, SE & $10.621 \pm 0.082$ & $0.542 \pm 0.012$ & $4.320 \pm 0.116$ & $0.034 \pm 0.001$ \\
\hline Site 2, Mean, SE & $10.482 \pm 0.071$ & $0.517 \pm 0.010$ & $4.064 \pm 0.113$ & $0.032 \pm 0.001$ \\
\hline Site 3, Mean, SE & $9.489 \pm 0.130$ & $0.336 \pm 0.010$ & $3.174 \pm 0.131$ & $0.023 \pm 0.002$ \\
\hline Site 4, Mean, SE & $9.382 \pm 0.122$ & $0.349 \pm 0.010$ & $3.201 \pm 0.132$ & $0.026 \pm 0.008$ \\
\hline
\end{tabular}

Site 1: Kharwari Baba facing north.

Site 2: Kharwari Baba facing east

Site 3: Pechi facing north

Site 4: Pechi facing west south

Table 2. Frequency distribution of the number of seeds per cone of Juniperus excelsa

\begin{tabular}{|c|c|c|c|c|c|c|c|}
\hline Number of seeds per cone & One & Two & Three & Four & Five & Six & Seven \\
\hline Site $1, \mathbf{N}$ & 0 & 7 & 17 & 30 & 30 & 15 & 1 \\
\hline Site $2, \mathbf{N}$ & 1 & 7 & 23 & 34 & 24 & 11 & 0 \\
\hline Site 3, N & 7 & 28 & 28 & 21 & 11 & 4 & 1 \\
\hline Site 4, N & 6 & 33 & 21 & 18 & 19 & 3 & 0 \\
\hline
\end{tabular}

Site 1: Kharwari Baba facing north.

Site 2: Kharwari Baba facing east

Site 3: Pechi facing north

Site 4: Pechi facing west south 


\section{Cutting test}

The cutting test of $J$. excelsa cones collected from site 1 were found Dry/Insect eaten and sound/wet $(n=36)$ followed by empty $(n=28)$ (Fig. 1). Whereas the cutting test of cones of collected from site 2 were found empty $(n=36)$ followed by Dry/Insect eaten $(n=34)$ followed by sound/wet ( $\mathrm{n}=30$ ) (Fig. 1).

The cutting test of cones collected from site 3 was found empty $(n=42)$ followed by Dry/Insect eaten $(n=38)$ followed by Sound/wet $(n=20)$ (Fig. 1). Whereas the cutting test of cones collected from site 4 were found Dry/Insect eaten $(n=48)$ followed by empty $(n=36)$ followed by sound/wet (n=16) (Fig. 1).

We also studied the relationship between these parameters. There was a positive correlation between cone diameter and cone weight (Fig. 2), cone diameter and the number of seeds per cone (Fig. 3), and between cone weight and the number of seeds per cone (Fig. 4). The strongest correlation between all these studied parameters was found in sampling site 3 (Fig. 2c, 3c and 4c).

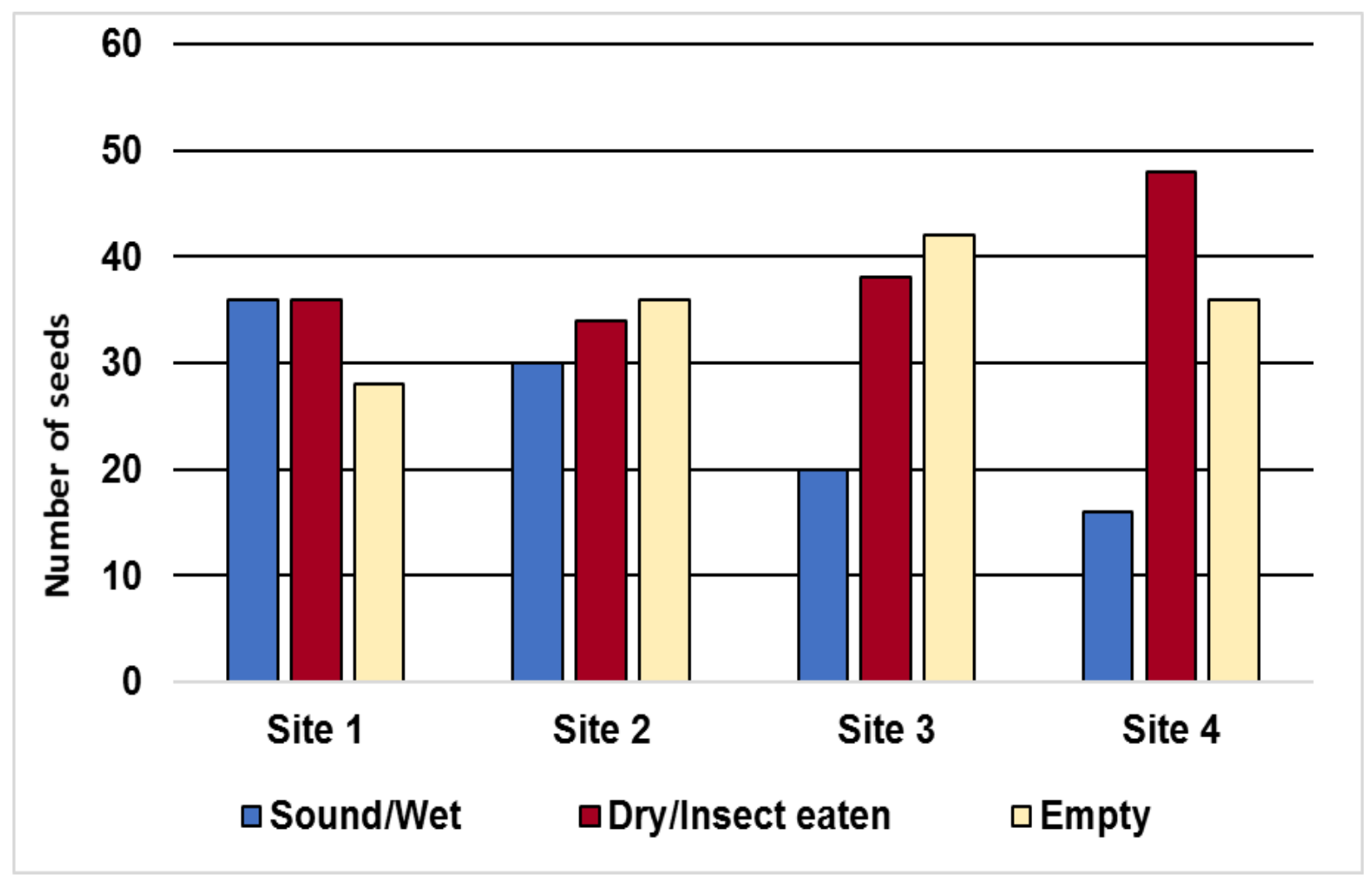

Figure 1. Cutting test of seeds of Juniperus excelsa

Site 1: Kharwari Baba facing north.

Site 2: Kharwari Baba facing east

Site 3: Pechi facing north

Site 4: Pechi facing west south 

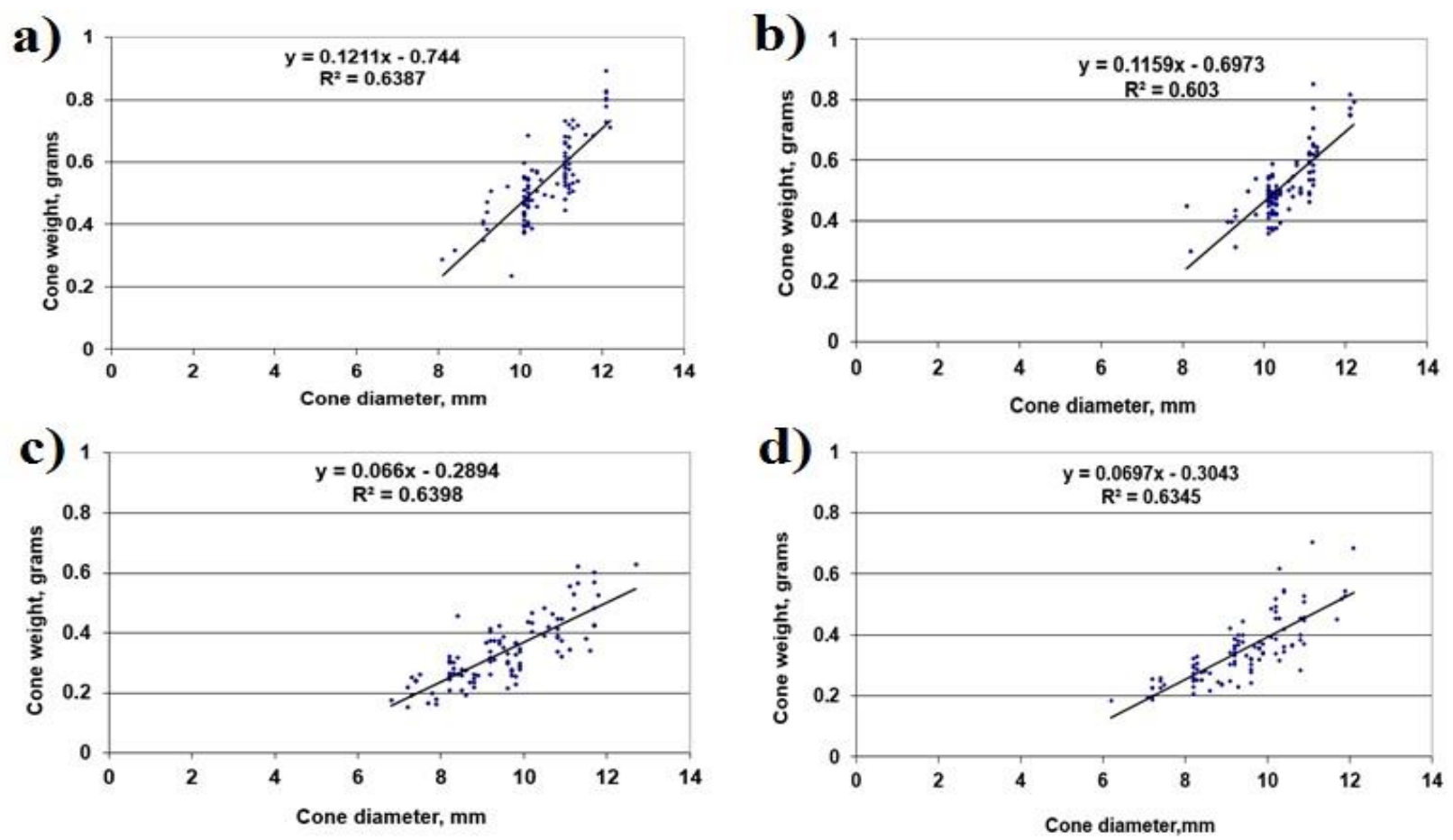

Figure 2. Cone diameter vs cone weight of Juniperus excelsa (a) Site 1: Kharwari Baba facing north, (b) Site 2: Kharwari Baba facing east, (c) Site 3: Pechi facing north, (d) Site 4: Pechi facing west south
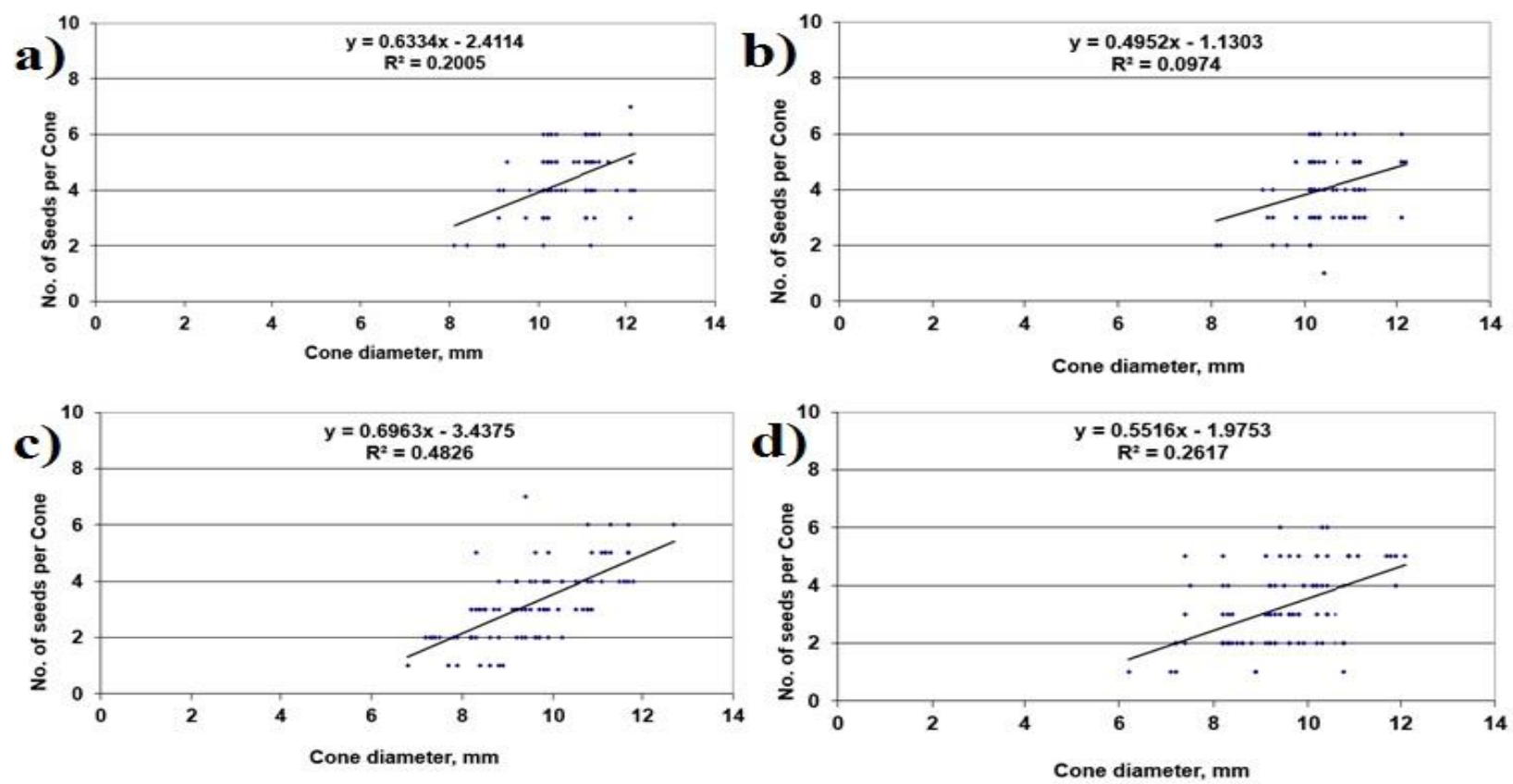

Figure 3. Cone diameter vs number of seeds per cone of Juniperus excelsa (a) Site 1: Kharwari Baba facing north, (b) Site 2: Kharwari Baba facing east, (c) Site 3: Pechi facing north, (d) Site 4: Pechi facing west south 

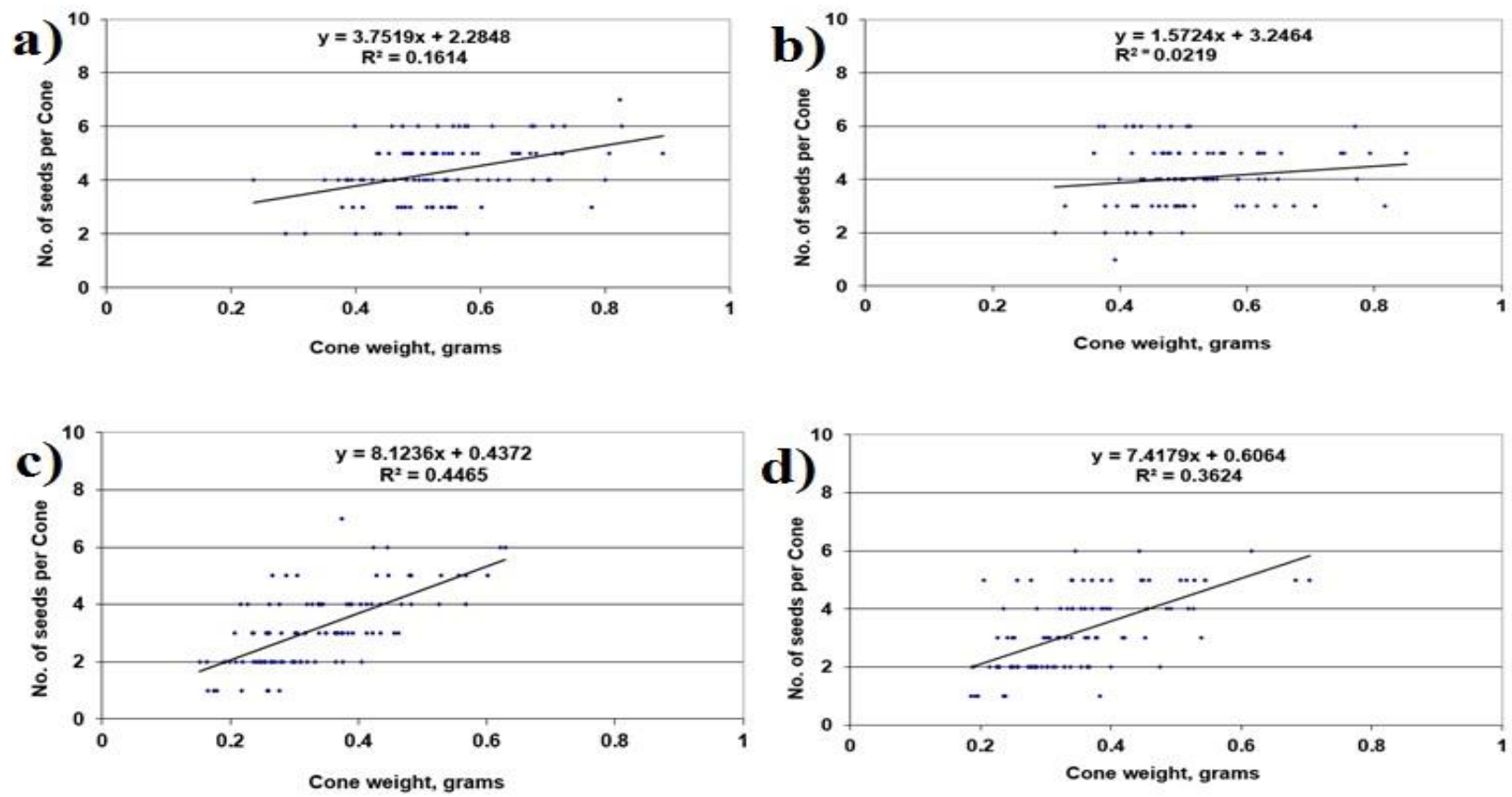

Figure 4. Cone weight vs number of seeds per cone of Juniperus excelsa (a) Site 1: Kharwari Baba facing north, (b) Site 2: Kharwari Baba facing east, (c) Site 3: Pechi facing north, (d) Site 4: Pechi facing west south

\section{Discussion}

Cones and seeds play an important role in the reproductive biology of a specie. Many researchers have studied the various characteristics of seeds and cones of different conifers worldwide. In the present study, these characteristics were studied to obtain valuable information for $J$. excelsa at various locations of district Ziarat, compare these trait variations in relation to facing different aspects, and spatial variations. The current study is one of the first studies from the area on $J$. excelsa.

An average cone diameter was found to be similar from trees at all the sampling sites facing different aspects. These findings show that the aspect does not play any substantial role in determining cone diameter, cone weight, seed weight, and seed characteristics. However, the average cone diameter was larger at (Site 1 and 2). These sites are at higher altitudes and have colder temperature than site 3 and 4 (Table 1). However, the cones' size and diameters were generally larger in sites 1 and 2 than sites 3 and 4, probably due to the higher altitude and cold temperature. Thus, higher altitude and cold weather may have a positive impact on cone size.

Average cone weight was somewhat higher in sites 1 and 2 than in sites 3 and 4. An average number of seeds per cone was found in great numbers in sites 1 and 2 than in sites 3 and 4 . Not only large cones were observed to produce more seeds per cone, but the contribution of average seeds weight from larger cone was also higher.

Only a couple of studies were conducted on J. excelsa from the region. Sarangzai [4] has conducted a quantitative study on $J$. excelsa adjacent area (four districts) of northern part of Balochistan province. Along with juniper, only 33 species were found; herbs (nongrasses) were $(57 \%)$ followed by shrubs (28\%), whereas the grasses accounted for about $15 \%$ only. The density of juniper trees ranged from 88-376 stem/ha (mean: 214 ha);

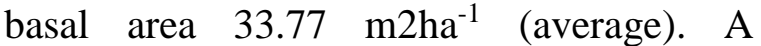


statistically significant correlation $(r=0.73$, $\mathrm{P}<0.001$ ) was reported between basal area and juniper density.

The study [4] reported adequate recruitment of J. excelsa seedlings. Sapling and seedling densities were $104+24$ ha on average. The highest average basal area and seedlings density was recorded from the northeast facing sloping. The percentage of filled seeds was $13-31 \%$, whereas the seedling density and its basal area was $82 \%$. Low quality seeds were produced in over-mature trees and the trees growing on dry spots. It was also reported that the variation in seed size and class frequency could be attributable to adaptive polymorphism [4].

The concentration of infection in J. excelsa was high in some areas. The variation in infection may be related to forest environments and topographic features between the different areas. Higher elevations range between 2800-3000 meters and south-western aspects appeared to favor the highest incidence of infection. There is a high potential from tree to tree spread in the study areas [4].

Thanos and Daskalakou [5] performed a study on seed weight and cone weight. They calculated the total number of seeds per cone, germinability of seeds per cone, seed weight, seed coat weight, germination (yes or no), cotyledons per seed. Cotyledon numbers showed considerable stability within individual trees and were statistically significantly correlated with seed weight $[5$, 6].

Large numbers of seeds were observed to be sound/wet in Kharwari Baba then Pechi however, the empty seeds were found less in Kharwari Baba than Pechi. The numbers of dry/insect eaten seeds were found more in Pechi than Kharwari Baba. Our result relating to filled seeds almost corresponds to the one that has been reported by Sarangzai [4]. It is suggested that the cold temperature has a positive impact and human intervention negatively impacts seeds characteristics. A large proportion of seeds were found empty in all locations with varying degrees. In a previous study with another species of Juniperus, Fuentes and Schups [7] has proposed that empty seeds may be an adaptation to prevent seed predation. However, in our study, the empty seeds were positively correlated with altitude therefore, the reason behind empty seeds demands further investigation.

Fuentes and Schupp [7] further reported that Utah juniper (Juniperus osteosperma) is one of most plant species that produce large numbers of fruits containing parthenocarpic or otherwise empty or inviable seeds. They tested the hypothesis that the production of empty fruits in this species results in reduced levels of predation on fertile seeds. It was estimated that the proportion of fruits with filled seeds in trees suffering high levels of fruit devastation by the seed-eating bird Parus inornatus and in adjacent trees similar in the crown and fruit-crop size but suffering insignificant predation. They found that the heavily attacked trees had higher proportions of filled seeds. Thus, juniper may benefit from producing fruits that contain no offspring. This is the first study to determine that empty seeds may decrease predation by vertebrate's seed eaters and determine discrimination based on seed filling at the level of whole plants. Zaidi et al. [8] reported the pharmacological screening of Arceuthobium oxycedri (Dwarf Mistletoe) of juniper forest of Pakistan. The study reported that the species of junipers face a serious danger by parasitic and epiphytic angiosperm, dwarf mistletoe, Arceuthobium oxycedri. The research site having world's second largest juniper forests faces many problems. Despite week natural regeneration capacity, higher number of unhealthy plants, slow growth rate, low vegetation cover, mature and over mature prevalence, the main concerns are due to 
human disturbances. The current study recommends initiation of long-term management and conservation programs in the area to avoid any further damage [8-11].

\section{Conclusion}

The present study conducted to study cone and seed characteristics of $J$. excelsa concluded that the aspects (facing direction) did not play any substantial role in determining cone diameter, cone weight, seed weight, and seed characteristics of $J$. excelsa. A positive correlation was observed between cone diameter and cone weight, cone diameter and number of seeds per cone. It was also concluded that higher altitude and cold weather may positively impact the seed characteristics of J. excelsa.

\section{Authors' contributions}

Conceived and designed the experiments: WK Muhammad \& KT Afrasiab, Performed the experiments: WK Muhammad \& KT Afrasiab, Analyzed the data: WK Muhammad, KT Afrasiab \& NS Imrana, Contributed materials/ analysis/ tools: T Momina, Wrote the paper: WK Muhammad, KT Afrasiab, NS Imrana \& T Momina.

\section{References}

1. Nabi S, Kaleemullah, Al-Kahraman Y, Tahira B, Hajira B, Rasool A, \& Muhammad A (2017). A review on Juniperus Excelsa: description, distribution and ecology, ethnobotany and biological activities. Ind $A m \quad J$ Pharm Sci 4(3): 636-644.

2. Parvizi MM, Khazaii MM, Moein M, \& Zarshenas M (2018). Juniperus excelsa M.Bieb; a medicinal plant with various pharmacological activities. Tr Pharm Sci 4(1): 1-8.

3. Pirani A, Moazzeni H, Mirinejad S, Naghibi F \& Mosaddegh M (2011). Ethnobotany of Juniperus excelsa M. Bieb. (Cupressaceae) in Iran. Ethno Res Appl 9: 335-341.
4. Sarangzai AM (2000). Population structure and natural regeneration potential of Juniperus excelsa (M.bieb) in northern balochistan pakistan. University of Balochistan/ Department of Botany Balochistan.

5. Thanos CA \& Daskalakou EN (1993). Seed characteristics of Pinus brutia. Book of Papers, Int Sym Pinus brutia 10: 295-302.

6. Koukos PK, Papadopoulou KI, \& Papagiannopoulos AD (2002). Variation in the chemical composition of the berry oil of Juniperus oxecedrus L. Grown in North and west Greece. Holz als Rohund Werkstoff 60: 152-153.

7. Fuentes M, \& Schupp EW (1998). Empty seeds reduce seed predation by birds in Juniperus osteosperma. Evol Ecol 12: 823-827.

8. Zaidi AM, Huda A, Sidney, \& Crow A (2006). Pharmacological Screening of Arceuthobium oxycedri (Dwarf Mistletoe) of Juniper Forest of Pakistan. J Biol Sci (2): 56-59.

9. Adams RP, Morris JA \& Schwarzbach AE (2008). Taxonomic study of Juniperus excelsa and J. polycarpos using snps from nrdna and cp trnc-trnd, plus essential oils and rapd data. Phytologia 90(2): 208-225.

10. Shanjani PS (2003). Nitrogen Effect on Callus Induction and Plant Regeneration of Juniperus excelsa. Int J Agri Biol 5: 419-422.

11. Stankov S, Fidan H, Petkova Z, Stoyanova M, Prtkova N, Stoyanova A, Semerdjieva I, Radoukova T \& Zheljazkov VD (2020). Comparative Study on the Phytochemical Composition and Antioxidant Activity of Grecian Juniper (Juniperus excelsa M. Bieb) Unripe and Ripe Galbuli. Plants 9(9): 1207. 